\title{
KANDUNGAN BLACK CARBON PADA PARTIKULAT UDARA HALUS DAN KASAR DALAM UDARA AMBIEN DI DAERAH SERPONG - TANGERANG
}

\author{
Rita Mukhtar ${ }^{1)}$, Esrom Hamonangan ${ }^{1)}$, Hari Wahyudi'1), Muhayatun Santoso2), Diah Dwiana Lestiani ${ }^{2)}$
}

(Diterima tanggal 15-11-2011; Disetujui tanggal 14-03-2012)

\begin{abstract}
ABSTRAK
KANDUNGAN BLACK CARBON PADA PARTIKULAT UDARA HALUS DAN KASAR DALAM UDARA AMBIEN DI DAERAH SERPONG - TANGERANG. Black carbon (BC) merupakan bentuk impuritas dari karbon hasil pembakaran tidak sempurna bahan bakar fosil atau pembakaran biomassa. Black carbon memiliki pengaruh yang signifikan terhadap perubahan iklim melalui sifatnya yang mampu menyerap sinar matahari karena merupakan gas rumah kaca. Sumber utama BC yaitu sumber antropogenik, termasuk pembakaran biomas pembakaran tidak sempurna, kendaraan bermotor khususnya diesel serta sumber industri seperti pembakaran batu bara. Konsentrasi $\mathrm{BC}$ pada partikulat halus yang berukuran kurang dari $2,5 \mu \mathrm{m}\left(\mathrm{PM}_{2,5}\right)$ lebih dari $10 \%$ partikulat udara halus sehingga sangat penting dilakukan penentuan secara tepat. Pada penelitian ini, metode penentuan $\mathrm{BC}$ pada partikulat udara halus $\left(\mathrm{PM}_{2.5}\right)$ dan partikulat udara kasar $\left(\mathrm{PM}_{2.510}\right)$ berdasarkan metode reflektansi menggunakan alat EEL Smoke Stain Reflectometer. Pengambilan sampel dilakukan dengan menggunakan Gent Stacked Filter Unit sampler, lima kali seminggu di empat lokasi di daerah Serpong pada tahun 2008 yaitu di Batan Indah, BSD, Setu, dan Pusarpedal serta pada tahun 2009 di daerah Tangerang, yaitu di Curug, Jatiuwung, Islamic Village Lippo Karawaci, dan Cikupa. Hasil penentuan konsentrasi BC di daerah Serpong pada partikulat udara halus berkisar antara 2,31-3,76 $\mu \mathrm{g} / \mathrm{m}^{3}$, sedangkan pada partikulat udara kasar berkisar antara $0,72-1,54 \mu \mathrm{g} / \mathrm{m}^{3}$. Rasio konsentrasi BC terhadap konsentrasi massa $\mathrm{PM}_{2.5}$ untuk daerah Serpong berkisar antara $13-20 \%$, sedangkan rasio $\mathrm{BC}$ terhadap konsentrasi massa pada partikulat udara kasar sekitar 3-5\%. Jika dibandingkan konsentrasi BC di partikulat udara halus dan kasar maka $\mathrm{BC}$ terkonsentrasi dominan pada partikulat udara halus, hal ini disebabkan karena $\mathrm{BC}$ umumnya berasal dari sumber antropogenik/aktivitas manusia yang partikel berukuran kurang dari 2,5 um. Konsentrasi BC di Serpong dan Tangerang masih dalam level yang sama dengan BC di Bandung dan Lembang. Perbandingan rasio BC di Serpong terhadap partikulat massa dengan beberapa negara lain di Asia yang menggunakan metoda dan formula yang sama, hal ini dilakukan untuk mengetahui distribusi tingkat pencemaran BC di Asia masih berada dibawah $\mathrm{BC}$ di negara-negara lain.
\end{abstract}

Kata kunci: black carbon, $\mathrm{PM}_{2,5}, \mathrm{PM}_{2.5-10}$, reflektansi

\begin{abstract}
BLACK CARBON CONCENTRATIONS IN FINE AND COARSE AMBIENT PARTICULATE MATTER COLLECTED IN SERPONG-TANGERANG. Black carbon $(B C)$ is an impure form of carbon resulted from incomplete combustion of fossil fuel or biomass burning. Black carbon has significant impacts on climate change due to its light absorption capabilities which is green house gas. The main source of black carbon is anthropogenic source including biomass burning, incomplete combustion, motor vehicles especially diesel and industrial emissions such as coal combustion. Black carbon concentration in fine particulate matter which aerodinamic diameter less than $2.5 \mathrm{\mu m}\left(P M_{2.5}\right)$ usually more than $10 \%$ of the fine mass, therefore an accurate measurement of black carbon is important. In this study, BC of fine $\left(P M_{2.5}\right)$ and coarse particulate matter $\left(P M_{2.5-10}\right)$ was measured based on reflectance method using EEL Smoke Stain Reflectometer. Sampling of airborne particulate matters were carried out using Gent Stacked Filter Unit sampler, five times a week in four locations in Serpong area in 2008 covering Batan Indah, BSD, Setu and Pusarpedal, while in 2009 in Tangerang area covering Curug, Jatiuwung, Islamic Village Lippo Karawaci and Cikupa. BC concentrations in fine particulate matters collected in Serpong were ranged 2,31-3,76 $\mu \mathrm{g} / \mathrm{m}^{3}$, while in coarse particulate matters were $0,72-1,54 \mu \mathrm{g} / \mathrm{m}^{3}$. The ratio of BC to fine particulate matter $P M_{2.5}$
\end{abstract}

${ }^{1}$ PUSARPEDAL - Kementerian Lingkungan Hidup

${ }^{2}$ PTNBR - Pusat Teknologi Nuklir Bahan dan Radiometri

BATAN Badan Tenaga Nuklir Nasional 
in Serpong was $13-20 \%$, while the ratio of BC to coarse particulate matter $P_{2.5-10}$ was $3-5 \%$. BC concentrations were dominant in fine particulate matters compared to coarse particulate matters, because the BC is mainly from anthropogenic sources/human activities which the particles size is less than $2.5 \mu \mathrm{m}$. BC concentrations in Serpong and Tangerang is still the same level as in Bandung and Lembang area. Comparison of the ratio of BC to fine particulate mass in Serpong with other countries in Asia that used the same method and formula were also presented, to find the distribution level of BC pollution in Asia, which resulted that BC in Serpong and Tangerang were lower than other countries.

Keyword: black carbon, $\mathrm{PM}_{2,5}, \mathrm{PM}_{2.5-10}$, reflectance

\section{PENDAHULUAN}

Pencemaran udara yang disebabkan oleh partikulat halus $\left(\mathrm{PM}_{2,5}\right)$ di udara menjadi permasalahan yang serius dibicarakan baik di tingkat nasional maupun internasional. US EPA pada bulan Juli 1997 telah menjadikan $\mathrm{PM}_{2,5}$ sebagai standar kualitas udara ambien. $\mathrm{PM}_{2,5}$ dapat memberikan efek negatif terhadap kesehatan, mempengaruhi jarak pandang, perubahan iklim, dan perpindahan pencemaran antar wilayah ${ }^{[1]}$. Salah satu parameter yang berpotensi mencemari lingkungan yang demikian adalah Black Carbon (BC) atau Element Carbon (EC) atau Karbon Hitam.

Black Carbon di udara atmosfer sangat mendominasi penyerapan sinar matahari hingga 90\%. BC memiliki efek cukup kompleks pada perubahan iklim ${ }^{[1]}$. Sumber utama keberadaan BC di udara berasal dari antropogenik dan pembakaran biomassa, pembakaran tidak sempurna bahan bakar kendaraan bermotor dan sumber dari industri misalnya pembakaran batu bara untuk pembangkit energi, pembakaran tidak sempurna dari bahan bakar fosil, knalpot diesel, kompor tidak efisien yang umumnya dipakai di negara berkembang dengan membakar biomassa, kayu, semak-semak, atau sisa panen sebagai bahan bakar dan pembersihan hutan dan padang rumput.
Partikel karbon hitam adalah partikel dengan ukuran sangat kecil antara 0,01-1 mikron di atmosfer. Partikel karbon hitam menetap di atmosfer hanya beberapa minggu, tetapi menyebar pada rentang yang lebih panjang.

$\mathrm{BC}$ termasuk polutan berumur pendek dan merupakan penyumbang kedua paling penting pada pemanasan global. Faktanya, potensi karbon hitam diperkirakan memiliki 55\% efek penggerak radiatif dari karbon dioksida.

Beberapa hasil penelitian BC pada partikulat halus yang kurang dari 2,5 $\mu \mathrm{m}\left(\mathrm{PM}_{2,5}\right)$ di beberapa daerah perkotaan di Australia berkisar antara 10-40\%. Sedangkan BC pada $\mathrm{PM}_{2,5}$ di Indonesia khususnya di daerah Bandung dan Lembang memberikan kontribusi sekitar $18-25 \%{ }^{[2,3]}$.

Pada penelitian ini, akan ditentukan konsentrasi BC pada $\mathrm{PM}_{2,5}$ dan $\mathrm{PM}_{10}$. Lokasi pengambilan contoh uji di daerah Serpong-Tangerang dan sekitarnya, yang dilakukan dibeberapa titik pada tahun 2008 dan 2009.

Hasil analisis data akan dibandingkan dengan nilai black carbon di Bandung dan Lembang dan beberapa daerah perkotaan di Australia yang menggunakan metode dan formula yang sama. 
Cahaya yang direfleksikan atau diserap pada filter sampel bergantung pada konsentrasi partikel, densitas, refraksi indeks dan ukuran ${ }^{[4,5]}$. Jika dilakukan sampling pada filter, maka areal densitas dari filter tersebut dapat dinyatakan sebagai berikut:

$D=M * V / A$

$\operatorname{di~mana} A$ adalah luas area filter sampel $\left(\mathrm{cm}^{2}\right)$, $V$ adalah volume sampel $\left(\mathrm{m}^{3}\right)$ yang didapatkan berdasarkan laju alir pompa (L/min) dan waktu sampling (jam). Transmisi cahaya yang memiliki panjang gelombang melalui filter yang mengandung partikel debu udara, dinyatakan dalam persamaan berikut ${ }^{[6]}$ :

$$
I=I o \exp [-\varepsilon D / 100]
$$

dimana Io adalah transmisi cahaya melalui filter kosong, $I$ adalah transmisi melalui filter sampel, $\varepsilon$ adalah koefisien absorpsi untuk panjang gelombang tertentu $\left(\mathrm{m}^{2} / \mathrm{g}\right)$. Dengan asumsi bahwa absorpsi pada filter sampel yang diukur disebabkan oleh $\mathrm{BC}$, maka densitas $(D)$ merupakan densitas BC pada filter (BC) dimana dari persamaan 2 dapat dinyatakan sebagai berikut:

$\mathrm{BC}(\mu \mathrm{g} / \mathrm{cm} 2)=\{100 /(\varepsilon)\} \ln [\mathrm{Io} / \mathrm{I}]$

Untuk pengukuran $\mathrm{BC}$ menggunakan metode reflektansi cahaya, dimana cahaya yang berasal dari suatu sumber cahaya/lampu dihamburkan melalui annular photocel ke permukaan filter sampel, selanjutnya cahaya tersebut direfleksikan kembali ke photocell, maka panjang path cahaya tersebut adalah dua kali dari panjang path transmisi. Sehingga densitas BC dari pengukuran reflektans dari persamaan (3) dapat dinyatakan sebagai berikut:
$\mathrm{BC}\left(\mu \mathrm{g} / \mathrm{cm}^{2}\right)=\{100 /(2 \varepsilon)\} \ln [R o / R]$

$\mathrm{BC}\left(\mu \mathrm{g} / \mathrm{m}^{3}\right)=A / V^{*}\{100 /(2 \varepsilon)\} \ln [R o / R]$

di mana $A$ adalah luas area sampel $\left(\mathrm{cm}^{2}\right), V$ adalah volume sampling $\left(\mathrm{m}^{3}\right), R o$ adalah nilai reflektans dari filter kosong $(=100 \%)$ dan $R$ adalah nilai reflektans dari filter sampel (\%). Nilai reflektans yang diperoleh dari filter sampel merupakan nilai yang sebanding dengan jumlah $\mathrm{BC}$ pada filter. Untuk $\varepsilon$, Maenhaut 1998 mendapatkan nilai sebesar $5,27 \mathrm{~m}^{2} / \mathrm{g}$ dari eksperimen menggunakan pengukuran reflektansi cahaya putih pada filter Nuclepore diameter $47 \mathrm{~mm}$. Di samping persamaan (5) digunakan juga formula $\mathrm{BC}$ pada filter Nuclepore polikarbonat sebagai berikut :

$$
\begin{aligned}
\mathrm{BC}= & A / V \times\left[1000 \times \operatorname{LOG}\left(R_{\text {blank }} / R_{\text {sampel }}\right)+\right. \\
& 2,39] / 45,8
\end{aligned}
$$

di mana $R$ blank adalah nilai reflektans filter kosong (100\%), Rsampel adalah nilai reflektans filter sampel, $A$ adalah luas area filter sampel $\left(\mathrm{cm}^{2}\right)$ dan $V$ adalah volume sampel $\left(\mathrm{m}^{3}\right)$, dengan nilai 2,39 dan 45,8 adalah konstanta yang digunakan untuk filter Nuclepore Polikarbonat yang berasal dari ekperimen perhitungan $\mathrm{BC}$ menggunakan pembakaran asetilen (Prof. Dr. M. O. Andreae, Max Planck Institute of Chemistry, Mainz, Germany $)^{[7]}$. Persamaan (5) dan (6) memberikan nilai yang hampir sama ( $99 \%$ ) untuk perhitungan BC pada area filter sampel yang sama.

\section{METODOLOGI}

Pengambilan sampel partikulat udara dilakukan 5 kali dalam seminggu pada periode 25 Agustus - 3 November 2008 di Serpong, menggunakan alat Gent stacked filter unit 
sampler di 4 lokasi yaitu 2 lokasi di perumahan Komplek perumahan Batan Indah Serpong, dan Komplek Perumahan BSD sektor VIII. 1 (satu) lokasi di sekolahan SDN Setu Muncul, dan 1 (satu) lokasi di perkantoran Pusarpedal di Kawasan Puspiptek Serpong pada Th. 2008. Pada tahun 2009 dilakukan pengambilan contoh uji udara ambien di empat (4) titik sampling di sekitar Kabupaten Tangerang, yaitu; (1) Sekolah Menengah Kejuruan (SMK) Swasta YUPPENTEK-2 di Jl. Raya Km.4 Curug Tangerang, (2) Yayasan Pembina Lembaga Pendidikan PGRI (YPLP-PGRI) Daerah Banten yaitu SMP PGRI Jatiuwung di Jl. Gatot Subroto Km.5 No.4 Jatiuwung Kota Tangerang, (3) Islamic Village Lippo Karawaci di Tangerang, dan (4) RS.Selaras di Jl.Raya Cikupa Tangerang.

Filter yang digunakan adalah filter jenis Nuclepore polikarbonat yang terdiri dari dua ukuran pori filter yaitu filter berukuran $0,4 \mu \mathrm{m}$ selanjutnya disebut filter halus/fine yang akan digunakan untuk penentuan $\mathrm{BC}$ dalam $\mathrm{PM}_{2,5}$ dan filter berukuran pori $8 \mu \mathrm{m}$ selanjutnya disebut filter kasar/coarse, yang akan digunakan untuk penentuan $\mathrm{BC}$ dalam $\mathrm{PM}_{2,5}$. ${ }_{10}$. Penentuan konsentrasi $\mathrm{PM}_{2,5}$ dilakukan menggunakan metode gravimetri, yaitu konsentrasi ditentukan dari hasil pengurangan penimbangan berat sampel pada filter halus dengan berat filter halus kosong. Sebelum dilakukan penimbangan, filter dikondisikan pada ruang bersih dengan temperatur 18$25^{\circ} \mathrm{C}$ dan kelembaban maksimum kurang dari $55 \%$. Penentuan reflektans dari filter sampel dilakukan menggunakan alat EEL Smoke Stain Reflectometer, Diffusion Systems, Ltd, Model 43D.
Tata cara pengukuran reflektans BC menggunakan EEL smoke stain reflectometer adalah sebagai berikut ${ }^{[8]}$.

- Sampel yang akan diukur harus disimpan (dikondisikan) minimal 12 jam pada kondisi yang sama dengan alat EEL Smoke Stain Reflectometer. Kondisi diusahakan berada pada rentang suhu $18-25^{\circ} \mathrm{C}$ dan kelembaban maksimum mencapai $55 \%$.

- Sampel yang akan diukur harus ditangani menggunakan pinset yang bersih.

- Alat dihubungkan dengan tegangan jalajala 220 - $240 \mathrm{~V}$, tombol ON ditekan lalu dibiarkan minimal selama $1 / 2$ jam agar kondisi alat stabil.

- Angka pada display diatur hingga menunjukkan angka 00,0 dengan memutar tombol ZERO tanpa memasang Reflectometer Lead (RL) pada soket INPUT.

- Kabel RL dipasang pada soket INPUT, kemudian Reflectometer Lead (RL) diletakkan di atas standar putih. Tombol COARSE atau tombol FINE diputar hingga angka pada display menunjukkan angka 100 .

- Untuk pengukuran filter halus sampel partikulat udara, Reflectometer Lead (RL) diletakkan di atas standar abuabu, kemudian tombol COARSE dan FINE diputar hingga angka pada display menunjukkan angka yang sesuai dengan nilai yang didapatkan dari pengukuran 5 filter halus kosong pada standar abu-abu.

- Untuk pengukuran partikulat udara pada filter kasar, Reflectometer Lead (RL) diletakkan di atas standar abu- 
abu, kemudian tombol COARSE dan FINE diputar hingga angka pada display menunjukkan angka yang sesuai dengan nilai yang didapatkan dari nilai pengukuran 5 filter kasar kosong pada standar abu-abu.

- Sampel partikulat udara diletakkan pada standar putih dengan posisi sampel (debu) di atas, kemudian Reflectometer Lead (RL) diletakkan di atas sampel tersebut.

- Pengukuran dilakukan sebanyak 3 kali untuk masing-masing sampel.

\section{HASIL DAN PEMBAHASAN}

Kandungan rerata black carbon (BC) di 8 (delapan) titik sampling didaerah SerpongTangerang yang terdapat pada partikulat udara halus adalah $2,93 \mu \mathrm{g} / \mathrm{m}^{3}$ dan pada partikulat udara kasar adalah 1,10 $\mu \mathrm{g} / \mathrm{m}^{3}$, kisaran nilai di beberapa titik sampling konsentrasi BC disajikan pada Tabel 1. Kandungan rerata black carbon $(\mathrm{BC})$ yang tertinggi terdapat pada partikulat udara halus atau $\mathrm{PM}_{2,5}$, hal ini disebabkan karena $\mathrm{BC}$ umumnya berasal dari sumber antropogenik, yaitu dari kegiatan manusia yang mengakibatkan keberadaan partikulat berukuran kurang dari 2,5 $\mu \mathrm{m}$ di udara ambien. Kandungan BC yang terdapat pada partikulat udara halus dan kasar di beberapa titik sampling disajikan pada Grafik $1 \mathrm{~s} / \mathrm{d} 8$.

Tabel 1. Nilai Konsentrasi Black Carbon Pada Partikulat Udara Halus dan Kasar dalam Udara Ambien di Serpong - Tangerang

\begin{tabular}{|l|c|c|}
\hline \multirow{2}{*}{\multicolumn{1}{|c|}{ Lokasi }} & \multicolumn{2}{|c|}{ Rerata Konsentrasi Black Carbon } \\
\cline { 2 - 3 } & Fine $\left(\mu \mathrm{g} / \mathrm{m}^{3}\right)$ & Coarse $\left(\mu \mathrm{g} / \mathrm{m}^{3}\right)$ \\
\hline Pusarpedal & 2,31 & 0,72 \\
\hline Setu & 3.23 & 1.02 \\
\hline Batan Indah & 2.64 & 0.86 \\
\hline BSD & 2.43 & 0.94 \\
\hline Yuppentek & 3,17 & 1,29 \\
\hline Jatiuwung & 3,76 & 1,54 \\
\hline Islamic & 2,93 & 1,10 \\
\hline Selaras & 2,50 & 0,85 \\
\hline Rerata & 2,93 & 1,10 \\
\hline Standar deviasi & 0,57 & 0,33 \\
\hline Range & $(2,31-3,76)$ & $(0,72-1,54)$ \\
\hline
\end{tabular}

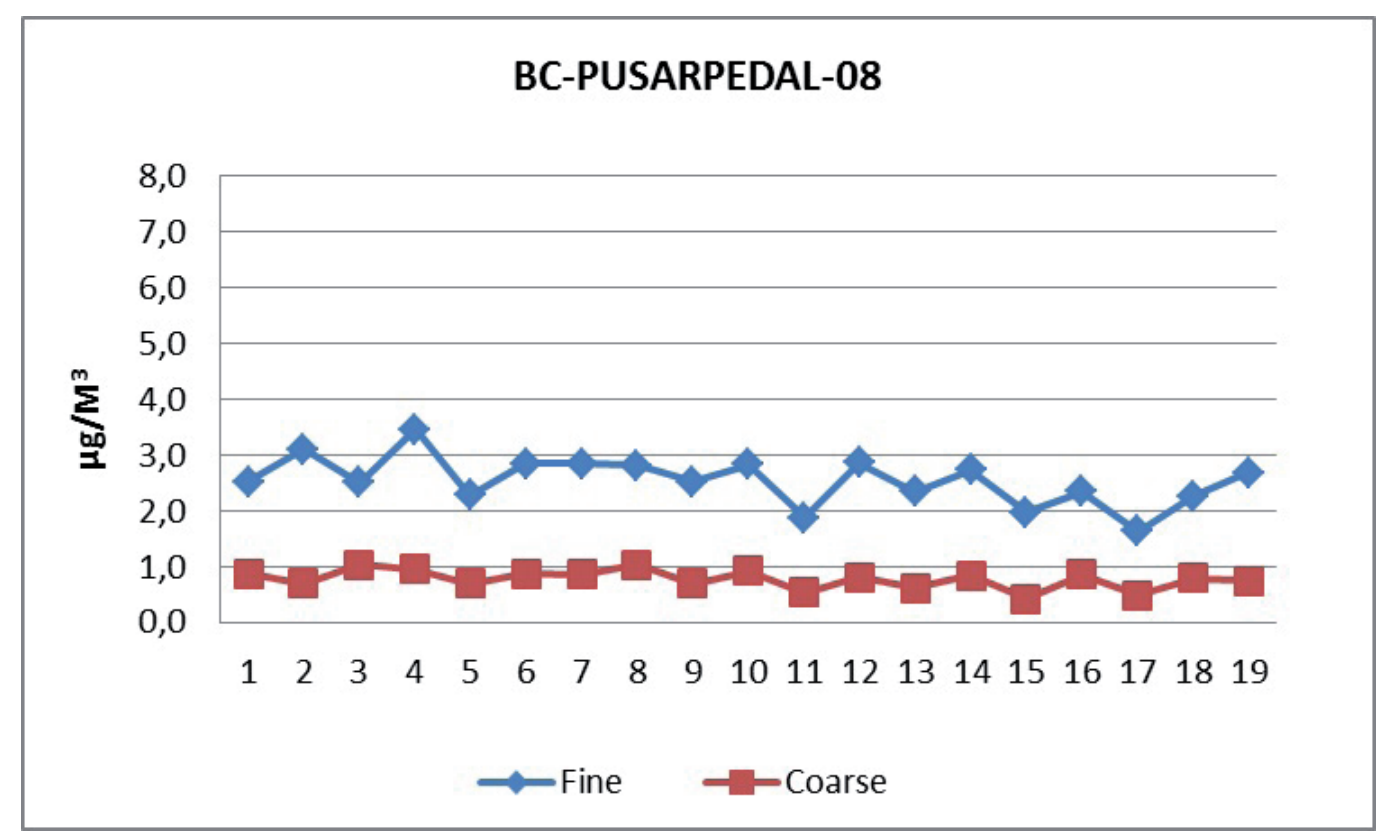




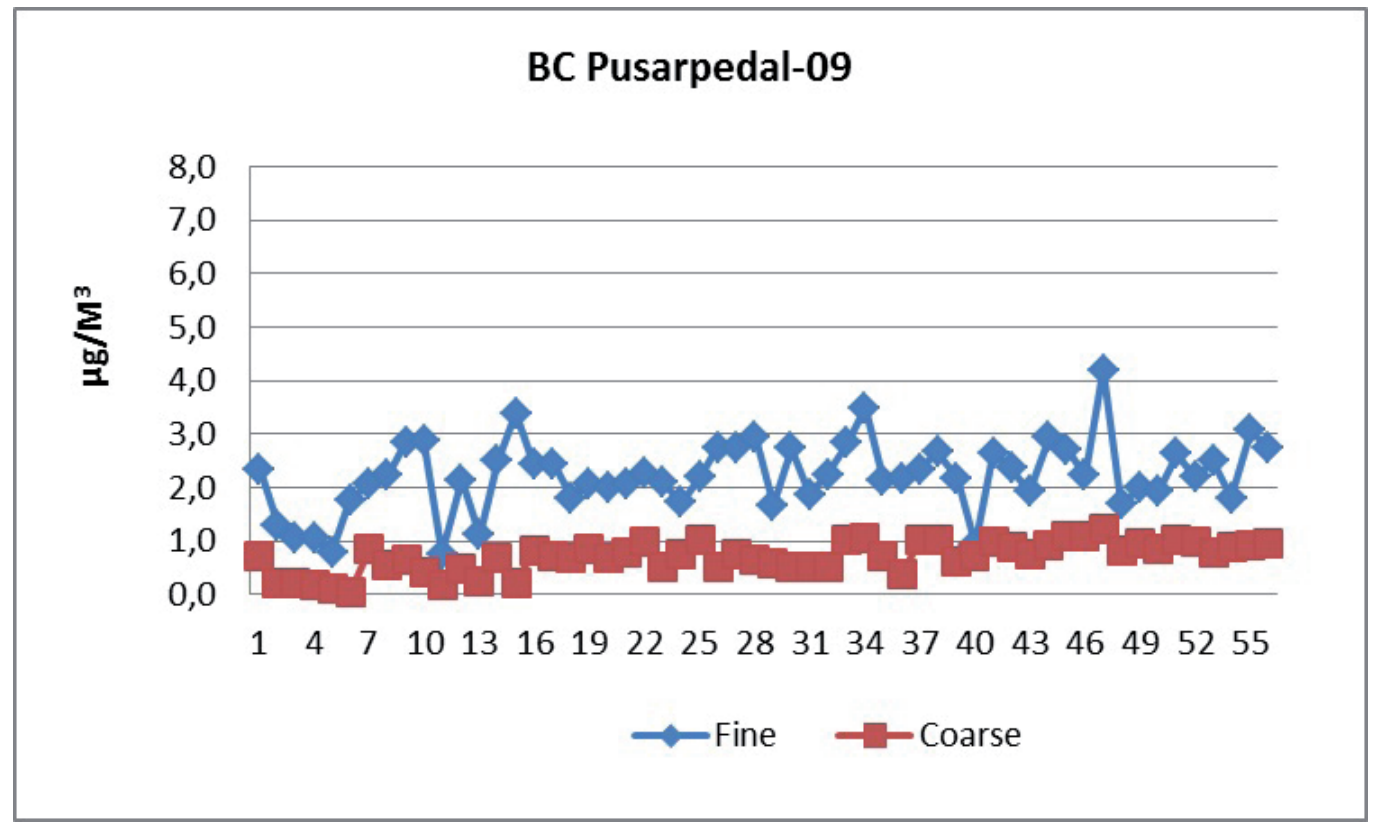

Grafik 1. Konsentrasi Black Carbon(BC) pada partikulat udara ambien halus dan kasar di Pusarpedal tahun. 2008 dan 2009

Konsentrasi BC di Pusarpedal hasil pemantauan th. 2008 tidak berbeda nyata dengan hasil th. 2009. Dengan rerata BC di partikulat halus $2,31 \mu \mathrm{g} / \mathrm{m}^{3}$ dan pada partikulat kasar 0,72 $\mu \mathrm{g} / \mathrm{m}^{3}$.
Kandungan rerata $\mathrm{BC}$ di Setu pada partikulat halus $3,23 \mu \mathrm{g} / \mathrm{m}^{3}$ dan pada partikulat kasar $1,02 \mu \mathrm{g} / \mathrm{m}^{3}$.

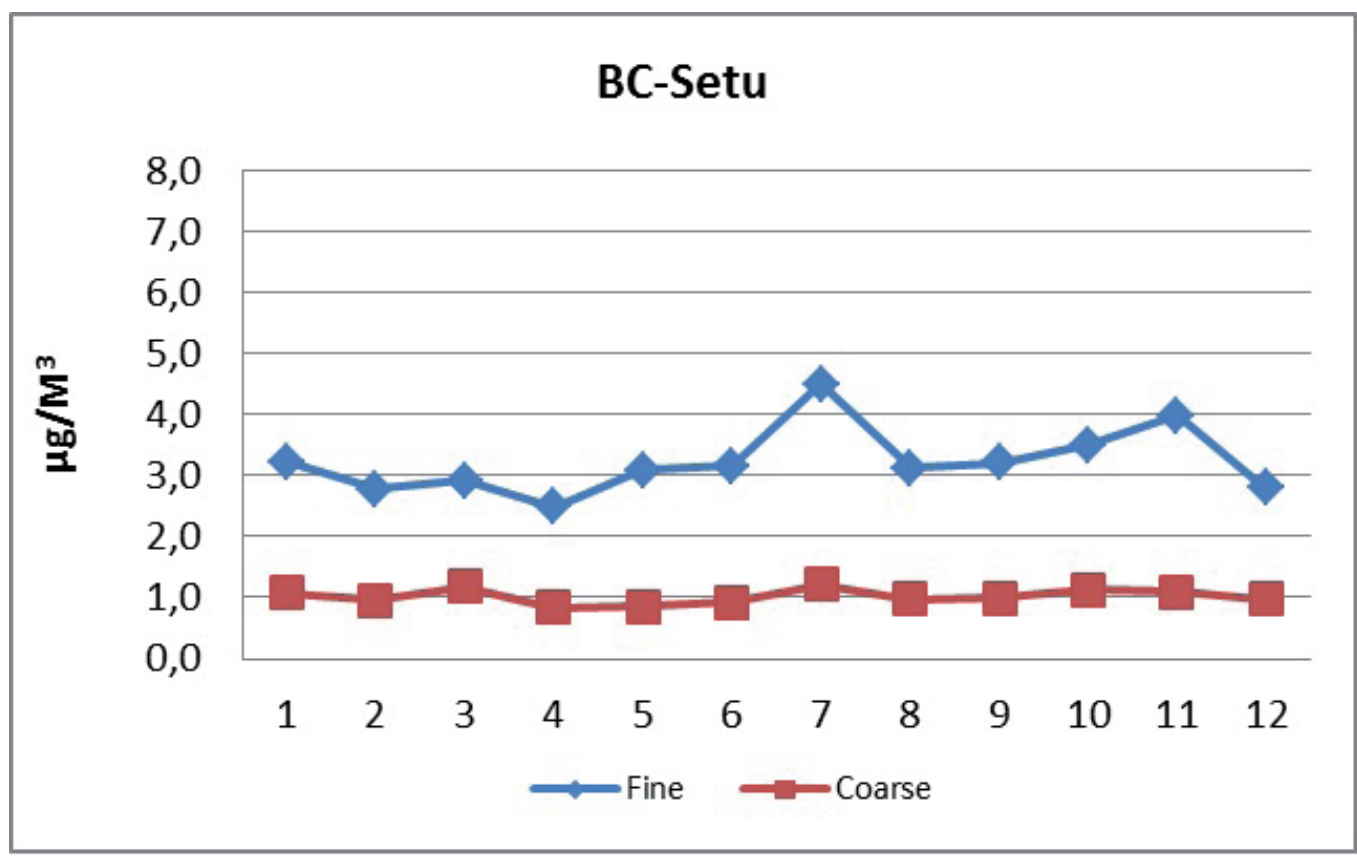

Grafik 2. Konsentrasi Black Carbon (BC) pada partikulat udara ambien halus dan kasar di Setu 


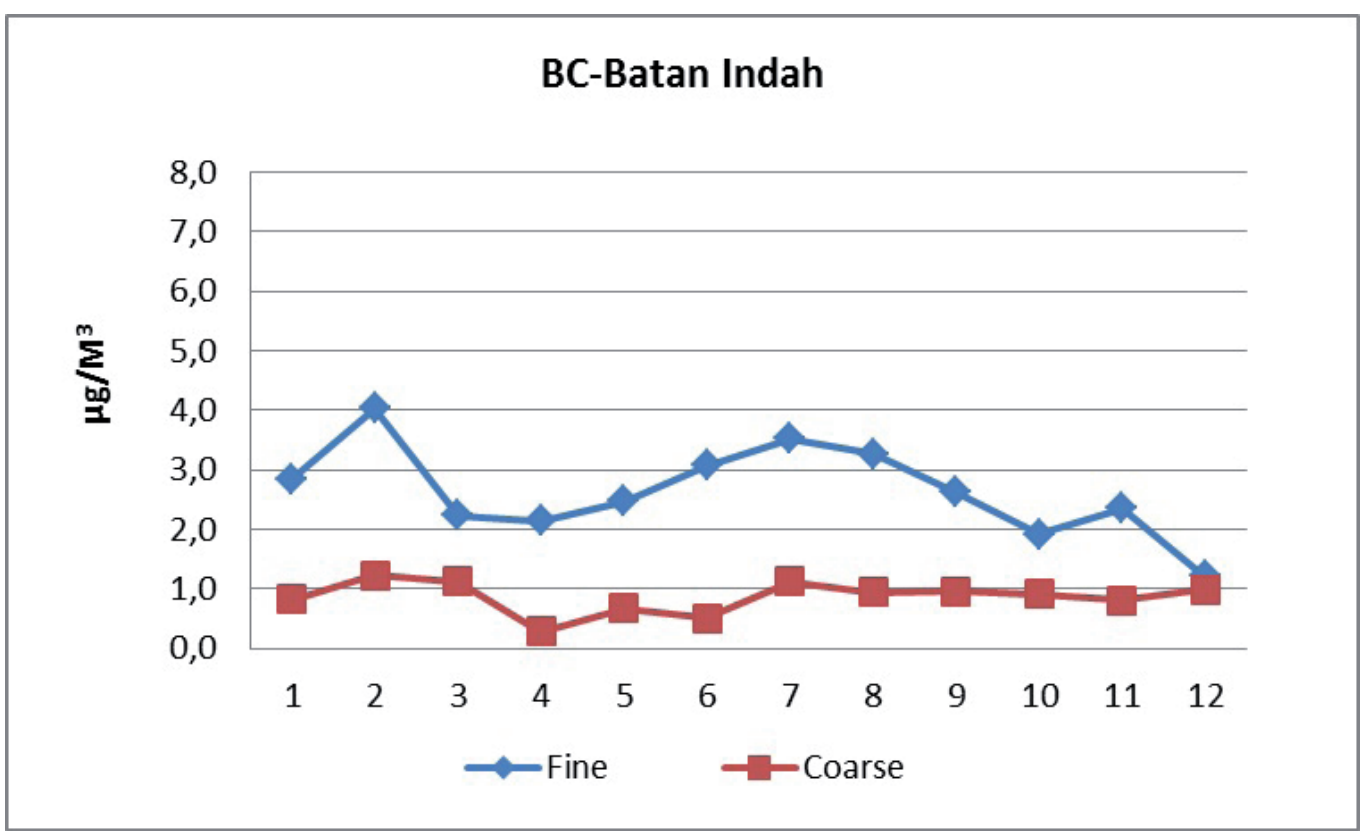

Grafik 3. Konsentrasi Black Carbon (BC) pada partikulat udara ambien halus dan kasar di Batan Indah

Kandungan rerata $\mathrm{BC}$ di Batan Indah pada partikulat halus $2,64 \mu \mathrm{g} / \mathrm{m}^{3}$ dan pada partikulat kasar $0,86 \mu \mathrm{g} / \mathrm{m}^{3}$.
Kandungan rerata $\mathrm{BC}$ di BSD pada partikulat halus $2,43 \mu \mathrm{g} / \mathrm{m}^{3}$ dan pada partikulat kasar $0,94 \mu \mathrm{g} / \mathrm{m}^{3}$.

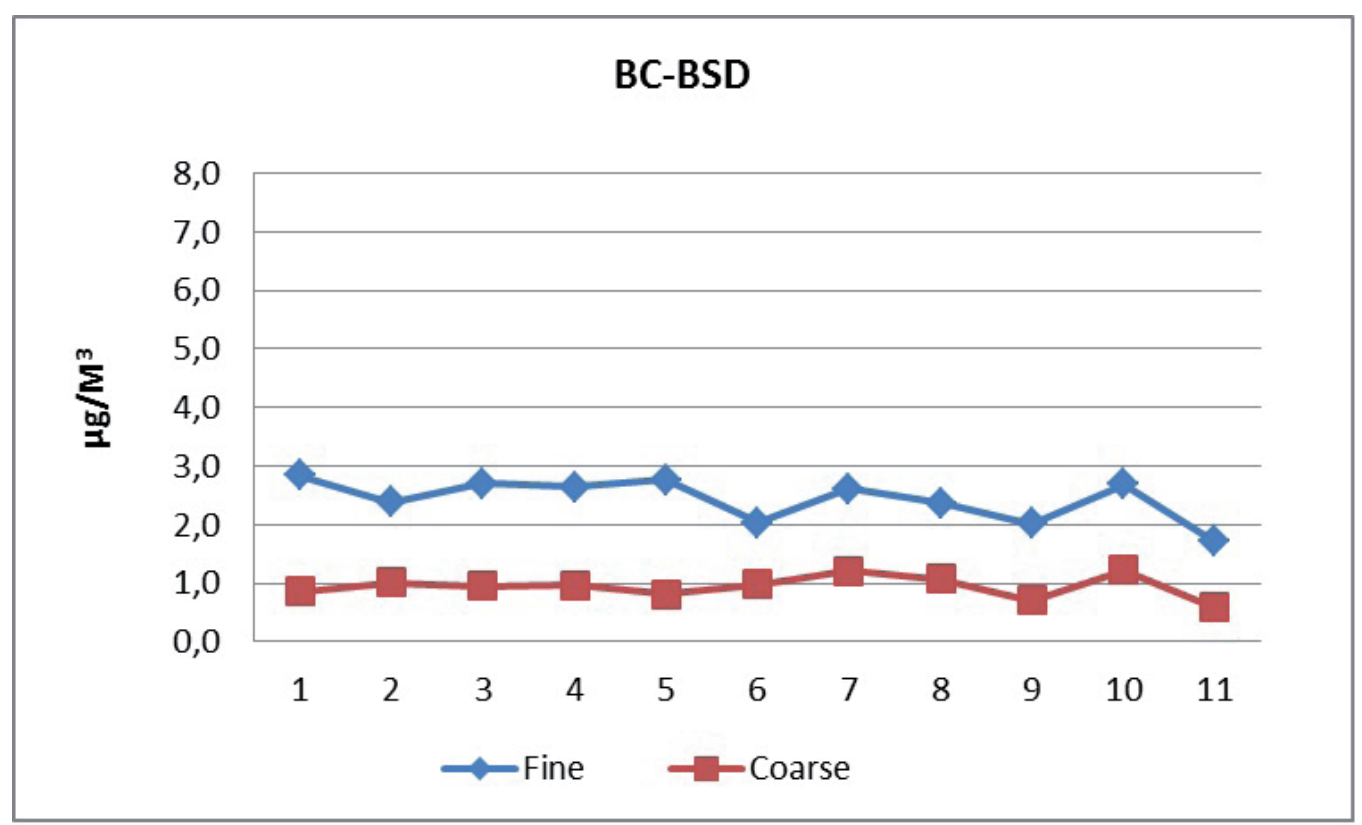

Grafik 4. Konsentrasi Black Carbon(BC) pada partikulat udara ambien halus dan kasar di BSD 


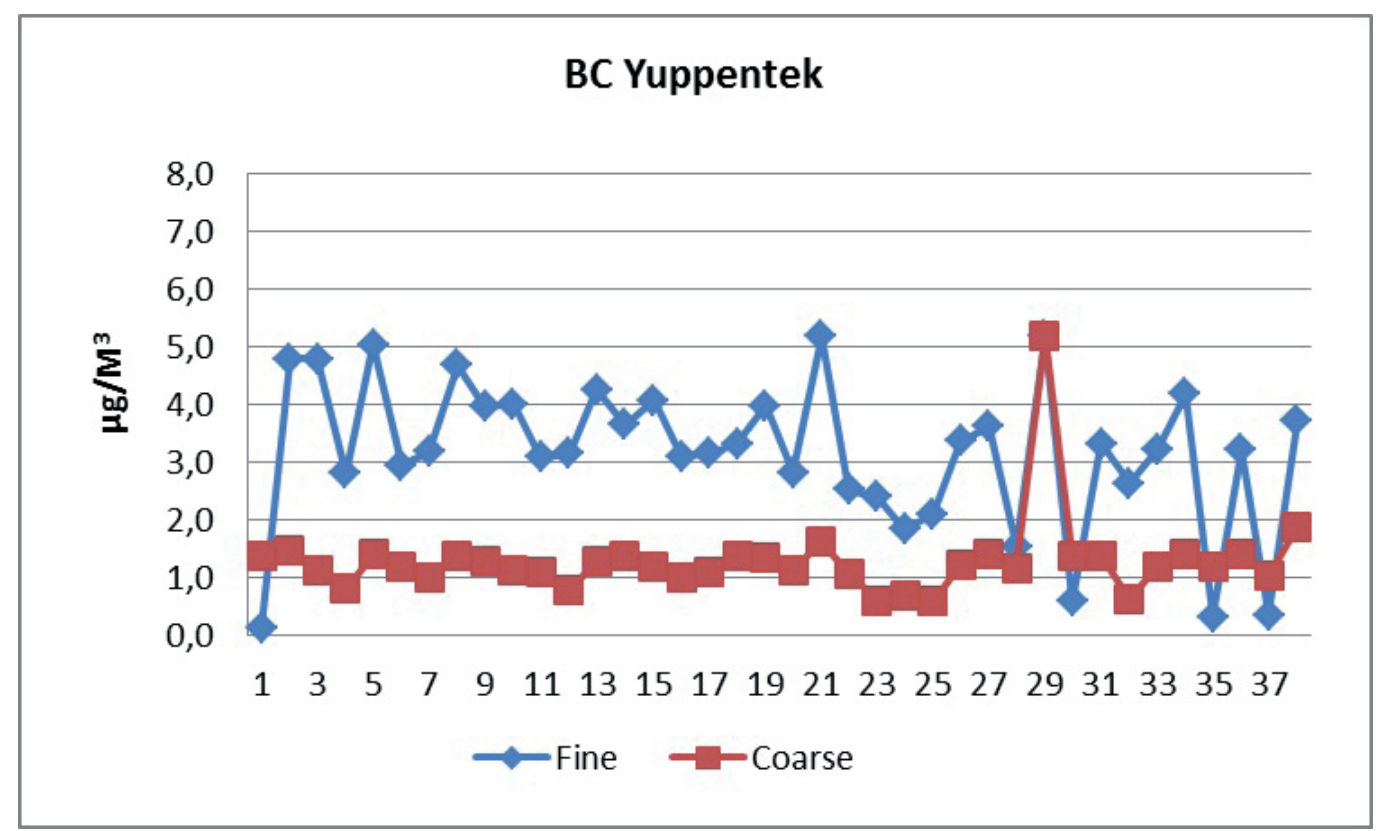

Grafik 5. Konsentrasi Black Carbon (BC) pada partikulat udara ambien halus dan kasar di Yuppentek

Kandungan rerata $\mathrm{BC}$ di Yuppentek pada partikulat halus $3,17 \mu \mathrm{g} / \mathrm{m}^{3}$ dan pada partikulat $\operatorname{kasar} 1,29 \mu \mathrm{g} / \mathrm{m}^{3}$.
Kandungan rerata $\mathrm{BC}$ di Jatiuwung pada partikulat halus $3,76 \mu \mathrm{g} / \mathrm{m}^{3}$ dan pada partikulat kasar $1,54 \mu \mathrm{g} / \mathrm{m}^{3}$.

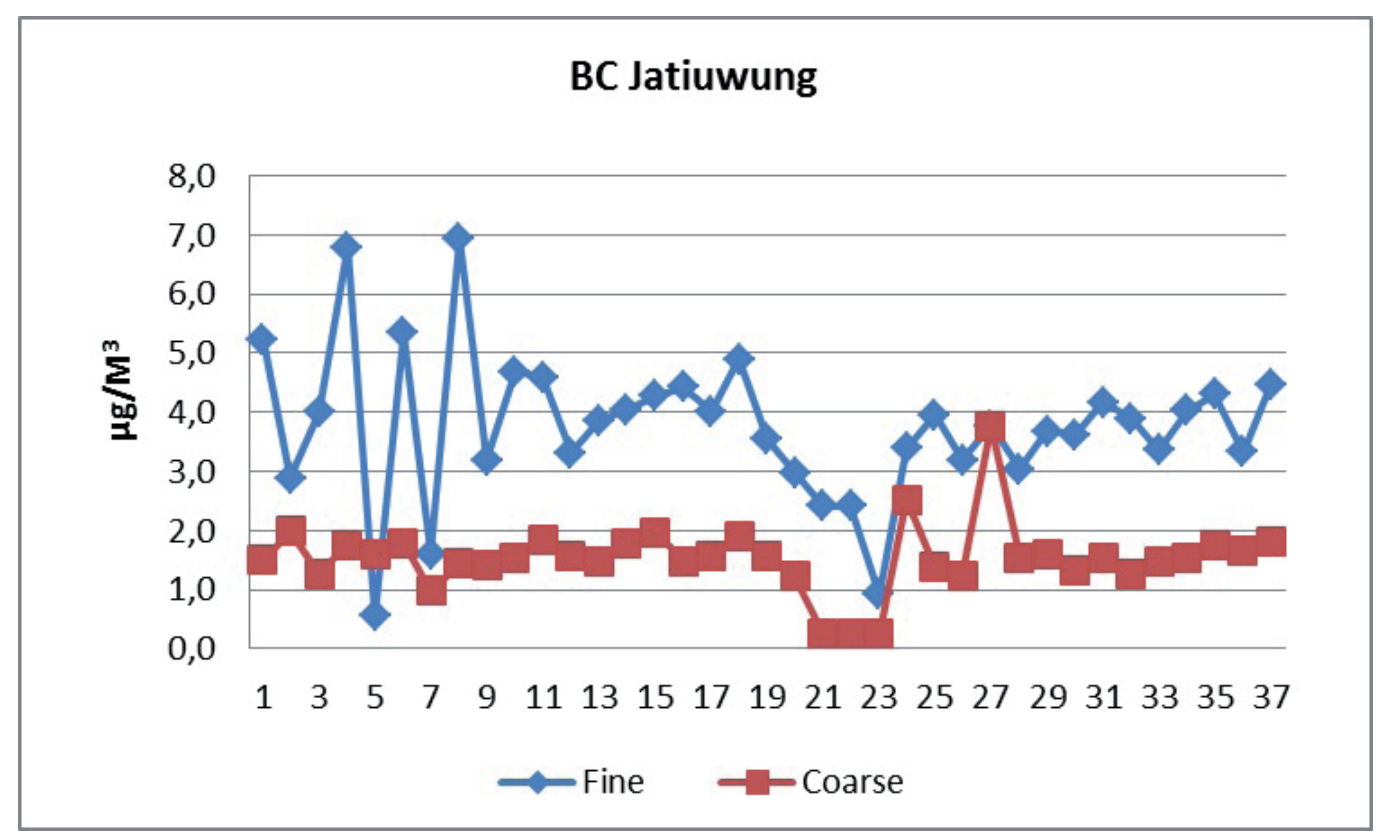

Grafik 6. Konsentrasi Black Carbon(BC) pada partikulat udara Ambien halus dan kasar di Jatiuwung 


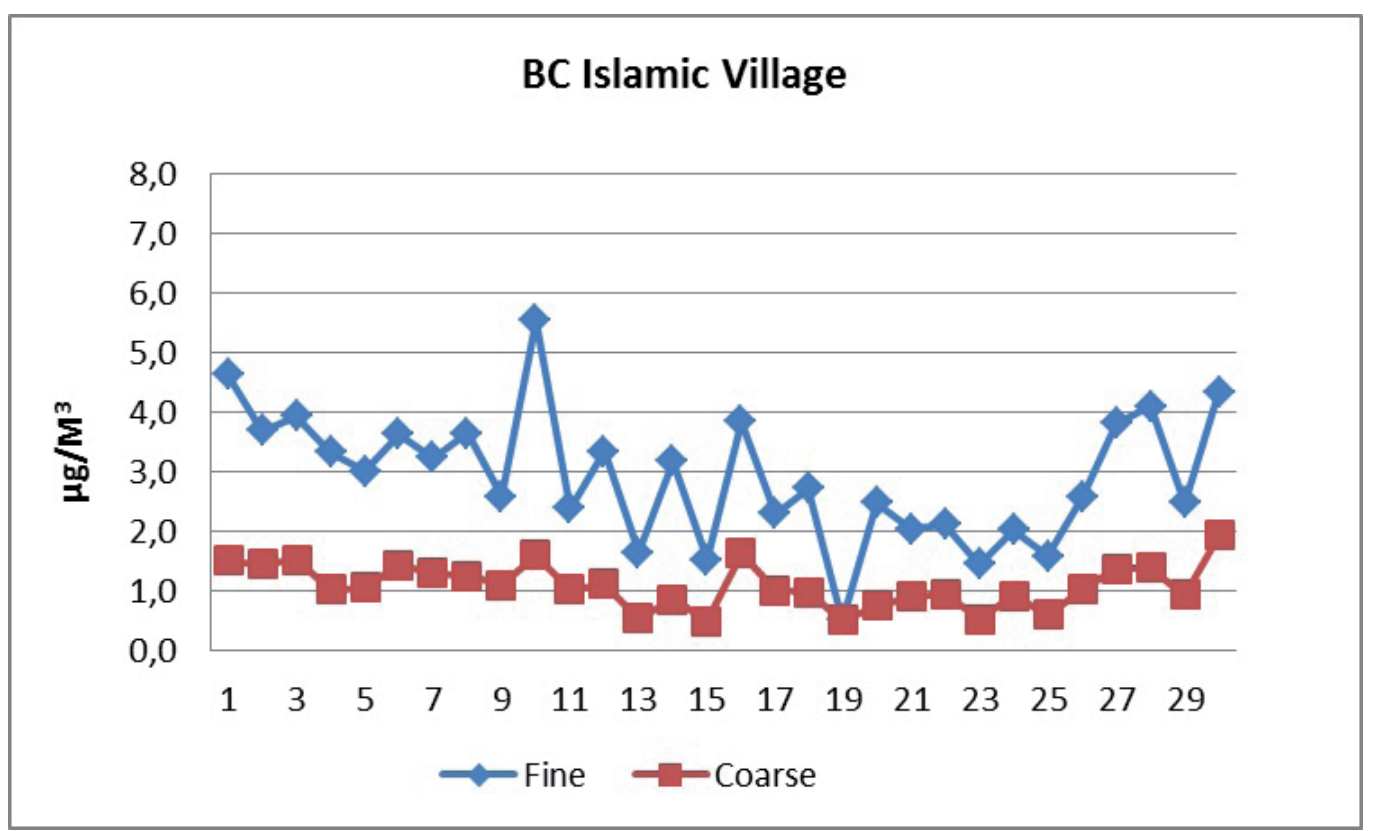

Grafik 7. Konsentrasi Black Carbon(BC) pada partikulat udara ambien halus dan kasar di Islamic village

Kandungan rerata $\mathrm{BC}$ di islamic Village Kandungan rerata $\mathrm{BC}$ di Selaras pada pada partikulat halus $2,93 \mu \mathrm{g} / \mathrm{m}^{3}$ dan pada partikulat halus $2,50 \mu \mathrm{g} / \mathrm{m}^{3}$ dan pada partikulat partikulat kasar $1.10 \mu \mathrm{g} / \mathrm{m}^{3}$. kasar $0,85 \mu \mathrm{g} / \mathrm{m}^{3}$.

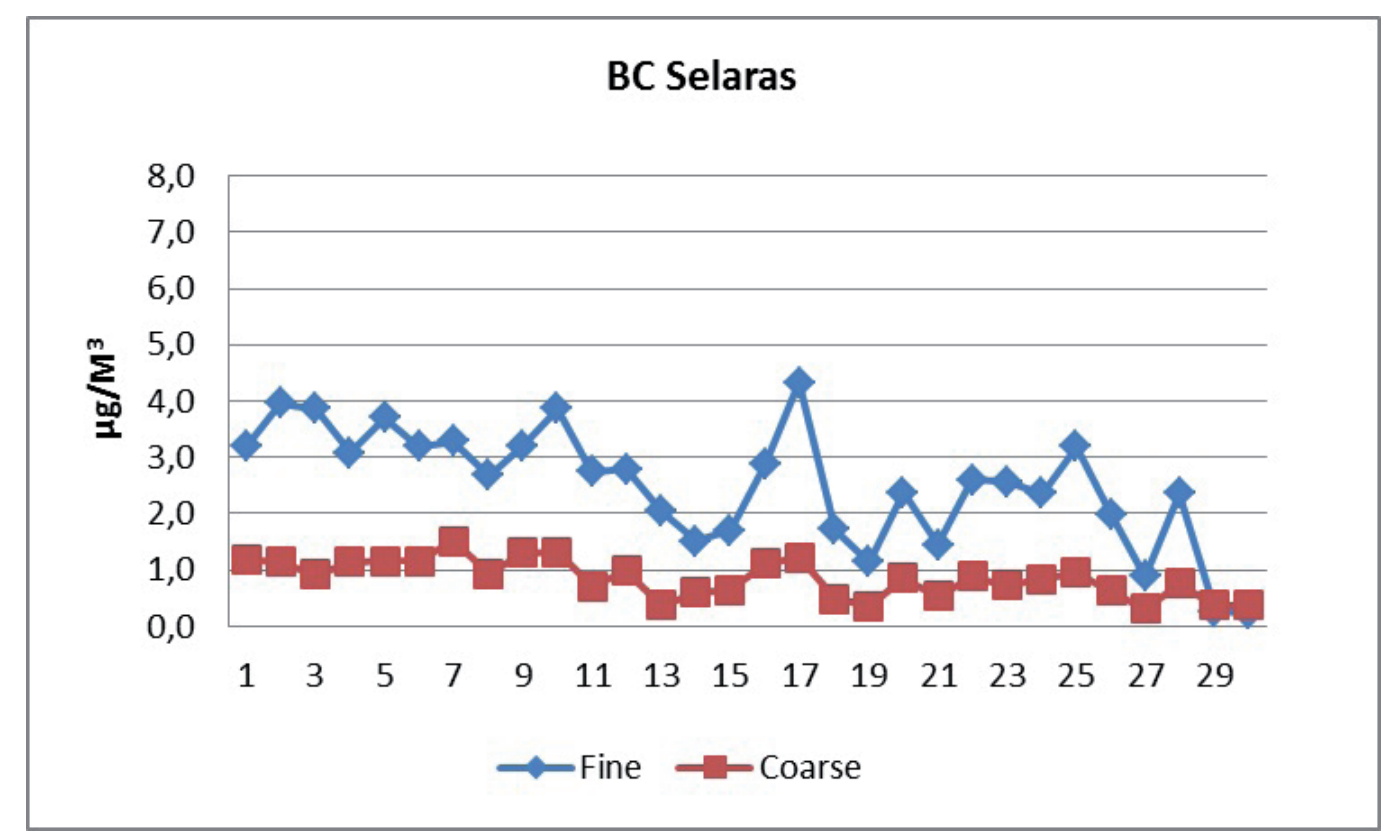

Grafik 8. Konsentrasi Black Carbon(BC) pada partikulat udara ambien halus dan kasar di Selaras 
Nilai presentase black carbon (BC) terhadap massa $\mathrm{PM}_{2.5}$ dan terhadap massa $\mathrm{PM}_{10}$ pada partikulat udara ambien di Serpong pada beberapa lokasi sampling, disajikan pada Tabel 2.

Tabel 2. Nilai Persentase Black Carbon Pada Partikulat Udara Ambien Halus (Fine) dan Kasar (Coarse) di Sekitar Serpong - Tangerang

\begin{tabular}{|c|c|c|}
\hline \multirow[b]{2}{*}{ Lokasi } & \multicolumn{2}{|c|}{$\% \mathrm{BC}$} \\
\hline & $\begin{array}{l}\text { terhadap partikulat } \\
\text { halus }\left(\mathrm{PM}_{2,5}\right)\end{array}$ & $\begin{array}{c}\text { terhadap } \\
\text { partikulat kasar } \\
\left(\mathrm{PM} 2,{ }_{5-10}\right)\end{array}$ \\
\hline Pusarpedal-08 & 16 & 5 \\
\hline Pusarpedal-09 & 13 & 4 \\
\hline Yuppentek & 17 & 4 \\
\hline Jatiuwung & 18 & 3 \\
\hline Islamic & 20 & 4 \\
\hline Selaras & 18 & 5 \\
\hline Setu & 16 & 4 \\
\hline BSD & 13 & 4 \\
\hline Batan Indah & 14 & 4 \\
\hline Rerata & 16 & 4 \\
\hline STD DEVIASI & 2,42 & 0,6 \\
\hline Range & $13-20$ & $3-5$ \\
\hline
\end{tabular}

Nilai rerata presentase BC didaerah SerpongTangerang yang terdapat pada partikulat halus (16\%) lebih tinggi jika dibandingkan dengan presentase BC terhadap partikulat kasar (4\%), hal ini disebabkan $\mathrm{BC}$ banyak terkonsentrasi pada partikulat yang lebih halus.

Kisaran presentase Black Carbon pada partikulat udara ambien pada partikulat halus di sekitar Serpong antara 13-20\%, hasil ini jika dibandingkan dengan $\mathrm{BC}$ pada partikulat halus di beberapa daerah perkotaan di Australia yaitu 10-40\% menunjukkan nilai BC di Serpong-Tangerang berada dalam range nilai tersebut, sedangkan jika dibandingkan dengan BC pada partikulat halus di daerah Bandung dan Lembang yaitu $18-25 \%$, nilai tersebut relatif sama.
Presentase BC pada partikulat halus secara signifikan lebih tinggi jika dibandingkan dengan $\mathrm{BC}$ pada partikulat kasar hal ini menunjukkan bahwa BC umumnya memberikan kontribusi sekitar $10-40 \%$ dari

partikulat udara halus yang berukuran kurang dari 2,5 $\mu \mathrm{m}\left(\mathrm{PM}_{2,5}\right)^{[2]}$. Oleh karena itu penentuan $\mathrm{BC}$ menjadi parameter yang sangat penting dalam karakterisasi partikulat udara.

\section{KESIMPULAN}

Kandungan black carbon di daerah SerpongTangerang yang terdapat pada partikulat udara halus adalah 2,92 $\mu \mathrm{g} / \mathrm{m}^{3}$ dan black carbon pada partikulat udara kasar adalah $1,16 \mu \mathrm{g} / \mathrm{m}^{3}$.

Presentase black carbon pada partikulat halus dan partikulat kasar di daerah SerpongTangerang menunjukkan nilai yang berada didalam range $\mathrm{BC}$ yang terdapat di beberapa daerah perkotaan di Australia, dan relatif sama dengan nilai BC di daerah Bandung dan Lembang.

Pemantauan tingkat konsentrasi BC dapat menjadi referensi dan sebagai peringatan dini apabila terjadi peningkatan konsentrasi, yang selanjutnya diharapkan dapat dimanfaatkan oleh pembuat kebijakan untuk menentukan langkah dan tindakan untuk mengurangi dan memperkecil sumber cemaran yang menjadi sumber utama cemaran BC.

Penelitian ini terlaksana atas kerjasama PUSARPEDAL dengan PTNBR BATAN Bandung. Penulis juga mengucapkan terimakasih kepada seluruh personil bidang pemantauan Pusarpedal dan kelompok teknik analisis radiometri Batan yang terlibat dalam sampling dan analisis pada penelitian ini 


\section{DAFTAR PUSTAKA}

1. COHEN, D.D., TAHA, G., STELCER,E.D., GARTON, D., BOX, G., 2000, The Measurement and Sources of Fine Particle Elemental Carbon at Several Key Sites in NSW over The Past Eight Years, Journal of Geophysical 102

2. LESTIANA D.D., SANTOSO, M., HIDAYAT, A., 2007, Karakteristik Black Carbon Partikulat Udara Halus PM2,5 di Bandung dan Lembang 20042005, Prosiding Seminar Nasional Sain dan Teknologi Nuklir PTNBR-Batan Bandung

3. MUHAYATUN, ACHMAD HIDAYAT, DIAH. Ambien Air Concentration of PM2,5 and PM10 in Bandung and Lembang in 2000-2006. Indonesian Journal of Science and Nuclear Technology 2008; X(1): 53-9
4. HOVARTH, H., Atmospheric light absorption - A review, Atmos. Environ., 27A (1993) 293-317

5. HOVARTH, H., Experimental calibration for aerosol light absorption measuremenst using the integrating plate method - Summary of data, Aerosol Science, 28 (1997) 1149-1161

6. EDWAR, J.D., OGREN, J.A., WEISS, R.A., and CHARLSON, R.J., Particle air pollutants, Atmos. Environ., 17 (1983) 2337-2341

7. TR OMPET T ER. W. J . a n d MARKWITZ.A., Ion Bean Analysis Results of Air Particulate Filter from Indonesia, 2005

8. ANONYMOUS, Manual EEL Smoke Stain Reflectometer, 2006kk 